\title{
Effects of Improving Forest Road Standards on Shortening the Arrival Time of Ground-based Firefighting Teams Accessing to the Forest Fires
}

\author{
Abdullah E. Akay ${ }^{*}$ (D), Ekaterina S. Podolskaia² (D), Zennure Uçar ${ }^{3}$ (i) \\ ${ }^{1}$ Bursa Technical University, Faculty of Forestry, 16310 Bursa, Turkey \\ ${ }^{2}$ Center for Forest Ecology and Productivity of the Russian Academy of Sciences, Laboratory of Forest \\ Ecosystems Monitoring, 117997 Moscow, Russian Federation \\ ${ }^{3}$ İzmir Katip Çelebi University, Faculty of Forestry, Forest Engineering Department, 35620 İzmir, Turkey
}

\begin{abstract}
In fighting against forest fires, it is crucial for the ground-based firefighting team to reach a fire area in critical response time in which the chance of controlling the fires is significantly high. Road networks are the key infrastructures that provide access to the forest areas for the protection of forest resources. In order to benefit from this important function of roads, especially in forested areas with high natural forest fire risk, they should be built in with adequate technical road standards since the low standards limit the fire truck speed that increases the arrival time of the firefighting team to the fire areas. Most of the forest roads in Turkey are Type-B secondary forest roads with low technical road standards (road width, curve radius, surface materials) that limit the speed of fire trucks. This paper aimed to evaluate the potential contribution of improving the standards of Type-B secondary forest roads in terms of increasing accessible forested areas in critical response time in the case of forest fire occurrence. The study area was Kahramanmaraş Forestry Enterprise Directorate (FED), where forests are sensitive to forest fires at the first degree. In the solution process, firstly, accessible forest areas by the firefighting teams located in the study area (six teams) according to the critical response time were determined by considering the existing road network in the study area. In the second scenario, the possible increase in the accessible forest areas with improved forest road standards and increased travel speed in forest roads was investigated. The results indicated that the areas that can be reached promptly by the firefighting teams in critical response time were $21 \%$ and $44 \%$ for considering existing roads and improved roads in the whole study area. On the other hand, the accessible forested areas in critical response time increased from $17 \%$ to $36 \%$ when standards of the forest roads were improved. It is indicated that improving road standards has a significant value to contribute the efficiency of firefighting activities if the practitioners implemented presented methodology.
\end{abstract}

Keywords: Forest roads, road standards, forest fires, firefighting, critical response time

\section{Introduction}

Wildfires are one of the vital disasters that affect the forest ecosystem particularly in forests with high natural forest fire risk. Besides, they threaten human life and cause serious property losses. In Turkey, large forest lands are annually affected by the forest fires, causing severe losses from an economic, environmental, and social aspects (Karabulut et al., 2013). The sustainability of forest resources are adversely affected by the forest fires which result in environmental impacts on forest ecosystems (Bilici, 2009).

For effective fighting against forest fires, the groundbased firefighting teams must arrive the fire scenes and start firefighting within the critical response time which is defined as the time when the probability of extinguishing forest fires rises significantly (Keramitsoglou et al., 2004). Therefore, it is important to determine the areas that the firefighting team can reach in critical response time. The critical response time is computed based on the fire sensitivity level of the forested areas (Akay et al., 2018).

The firefighting teams need to be positioned in the right locations in order to arrive the fire scenes promptly by using the shortest route. Since the firefighting teams are mostly carried to fire areas by fire-trucks, the accessible forests from a firefighting station within the critical response time can be determined based on the road length and design speed. About $66 \%$ of the forest roads in Turkey are classified as Type-B secondary forest roads, which have low standards and limited design speed (GDF, 2012). Type-B roads require major annual repairs due to the lack of adequate road standards. One way to expand the accessible forest areas that can be reached from a point within a specified time period is to improve the road standards increasing the design speed and eventually reducing travel time eventually. Thus, improving the road standards and efficiency of firefighting activities should be evaluated together in the most appropriate way. 
The decision support systems integrated with Geographical Information Systems (GIS) improve the effectiveness of fire management tasks such as planning, managing, and decision making (Burgan et al., 1998; Sampson et al., 2000; Kucuk and Unal, 2005). Previous studies investigated the integration of decision support systems with GIS techniques for solving vehicle routing problems (Manussaridis et al., 2007; Keenan, 2008). In some researches, vehicle routing was explored in realtime that allows for routes to be updated dynamically as a vehicle travels along a road network (Ichoua, 2000; Gendreau et al., 2001; Ghiani et al., 2003).

Previous studies suggested that increasing the design speed on current forest roads with low standards could increase firefighting response capabilities. However, no study has been encountered in the literature dealing with the effects of improving forest road standards on the efficiency of firefighting activities. In this study, GISbased network analysis was used to evaluate the effects of improving road standards on accessible forest areas by the ground-based firefighting team according to the critical response time. The study was implemented in Kahramanmaraş FED consisting of forests with high natural fire sensitivity. The Network Analyst tools of ArcGIS software was employed to determine the accessible forest areas by considering the existing and improved forest roads.

\section{Material and Methods \\ 2.1. Study Area}

The study was implemented in Kahramanmaraş FED which covers 10 Forestry Enterprise Chiefs (FECs) (Figure 1). The geographical location of the study area is $38.06 \mathrm{~N}-36.70 \mathrm{E}$ and $37.18 \mathrm{~N}-37.07 \mathrm{E}$. The study area is approximately 597,083 ha with approximately $45 \%$ covered by forest areas. In the FED, $44 \%$ of the forest area is a productive forest while the rest is degraded one. The forest areas are generally located in the transition region between the Mediterranean and the continental climate. The forested areas in Kahramanmaraş FED are classified as first-degree fire sensitive forests. There are six firefighting teams in the FED.

\subsection{GIS Database Generation}

In order to determine accessible forests in the critical response time using the GIS-based network analysis, digital data layers of land use types and road network were generated. In this process, 1:25000 scale topographic and forest management maps obtained from Kahramanmaraş FED in 2018 were used as base maps in ArcGIS software. The land use map of the study area was produced based on the forest management maps. Then, a new data layer of forest areas was produced by reclassifying the land use map using ArcGIS.

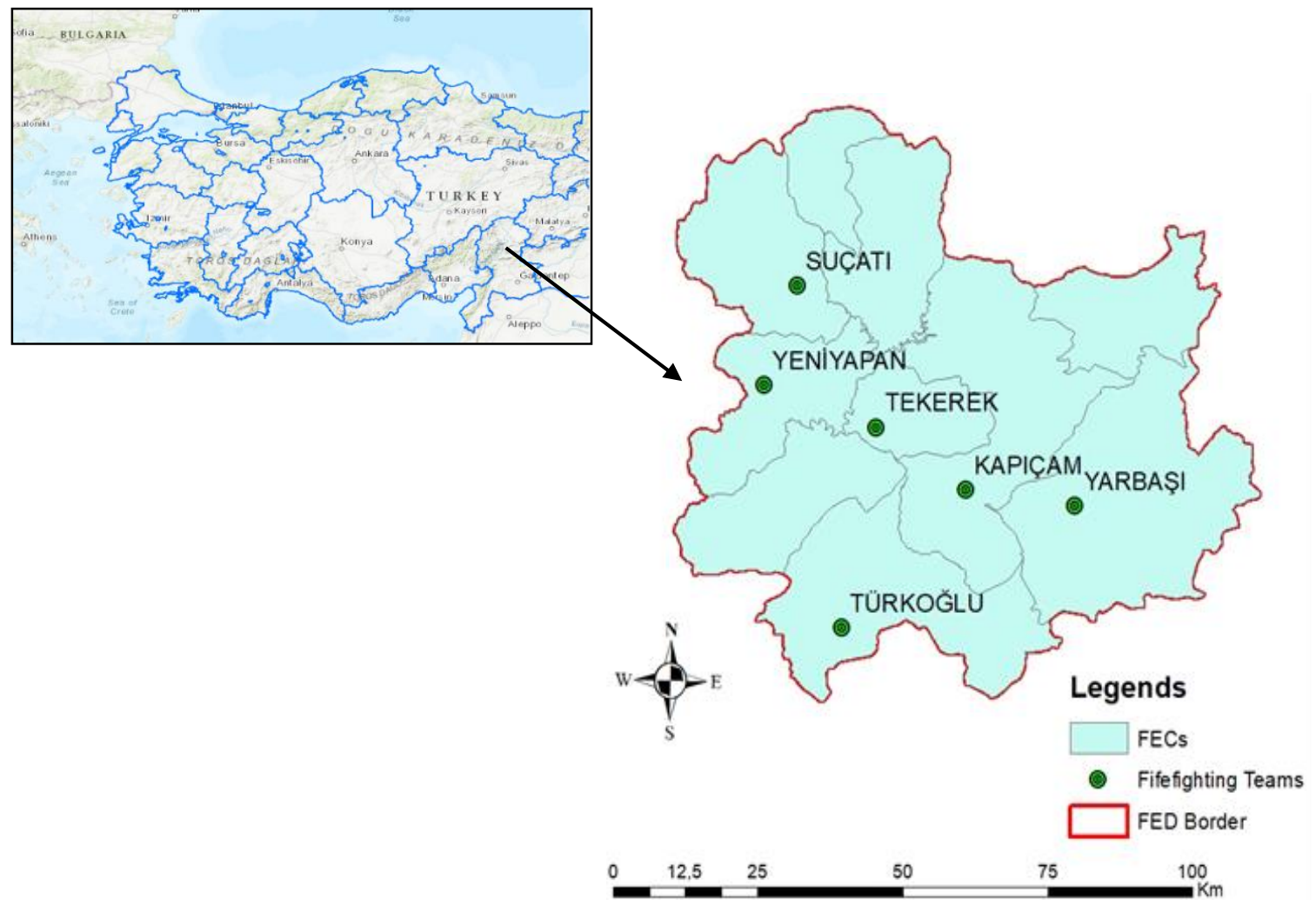

Figure 1. Study area

The average travel time of the fire trucks (carrying firefighting teams) for each road section was computed and included into the attribute table of the road network layer. The travel time was computed as a function of road length and average truck speed, which can vary based on road types and status. The road types in the study area were asphalt, gravel, and forest roads (Type-B), while the road status was classified as good, average and poor. The vehicle speed information recommended by some previous studies (Bilici, 2009; Akay et al., 2012) and the 
Traffic Inspection Branch Directorate (TIBD, 2010) have been taken into account. In the light of this information, the average fire truck speed for the road types is indicated in the Table 1.

Table 1. Average fire truck speed (km/hour) by road type and road status

\begin{tabular}{lccc}
\hline \multirow{2}{*}{ Road Type } & \multicolumn{3}{c}{ Road Status } \\
\cline { 2 - 4 } & Good & Medium & Poor \\
\hline Asphalt Road & 60 & 50 & 40 \\
Gravel Road & 50 & 40 & 30 \\
Forest Road & 30 & 25 & 20 \\
\hline
\end{tabular}

The accessible forested areas in critical response time considering improved forest roads (subject to road improvement construction and road surface construction) were determined in the second scenario. In this scenario, the average vehicle speed for improved forest roads was estimated as $40 \mathrm{~km} / \mathrm{hr}$, which is the average travel speed of a fire truck on a forest road with improved surface material (Akay et al., 2012). Then, travel time for each road section was computed using the Equation I, and inserted into the attribute table of the road network map (Şakar, 2010):

$$
\begin{aligned}
& t=\frac{l}{v} 60 \\
& t \quad: \text { travel time (minutes) } \\
& l \quad: \text { road length (km) } \\
& v: \text { average speed of fire truck (km/hour) }
\end{aligned}
$$

\subsection{Network Analysis}

The potential contribution of improving the standards of Type-B secondary forest roads in terms of increasing accessible forested areas in critical response time was evaluated with network analysis approach. In the solution process, firstly, accessible forest areas by the firefighting team according to the critical response time were determined by considering the existing road network in the study area. In the second scenario, the possible increase in the accessible forest areas was investigated for the forest roads with improved standards with high travel speed.

One of the most common methods used in the determination of an optimum route is network analysis where various parameters such as length, cost, and time are assigned to the road sections (Zhan, 1997). In this study, the network analysis based on "The New Service Area" method of the "Network Analyst" tool in ArcGIS was used to evaluate accessible forested areas in the critical response time for both scenarios. According to the forest fire sensitivity map of Turkey, developed by the General Directorate of Forestry (GDF), Kahramanmaraş FED is covered with first degree fire sensitive forest areas where critical response time is defined as 20 minutes (GDF, 2008).
In the application of New Service Area method, the locations of the firefighting teams were considered as service area points while the forest areas that can be reached within the critical response time were service areas. Then, the forest areas accessed within the critical response time were determined for both scenarios. Finally, the additional forest areas that can be reached by improving the road standards were determined by eliminating the accessible forested areas in the first scenario from the accessible forested areas in the second scenario.

\section{Results and Discussion}

\subsection{GIS Database}

The total road length was $15496.5 \mathrm{~km}$ in which about $51.5 \%$ was forest road (Type-B), $41.7 \%$ was gravel road, and $6.7 \%$ was asphalt road (Figure 2). It was found that the road type with the highest number of road section was gravel road, followed by the forest road and asphalt road. About $62.6 \%$ of the road network was in a good condition and $29.1 \%$ was in an average condition while the rest was in poor condition. In the case of road types, $100 \%$ of the asphalt roads, about $63.8 \%$ of the gravel roads, and $56.7 \%$ of the forest roads were in a good condition, indicating that they can provide reliable trafficking (Table 2).

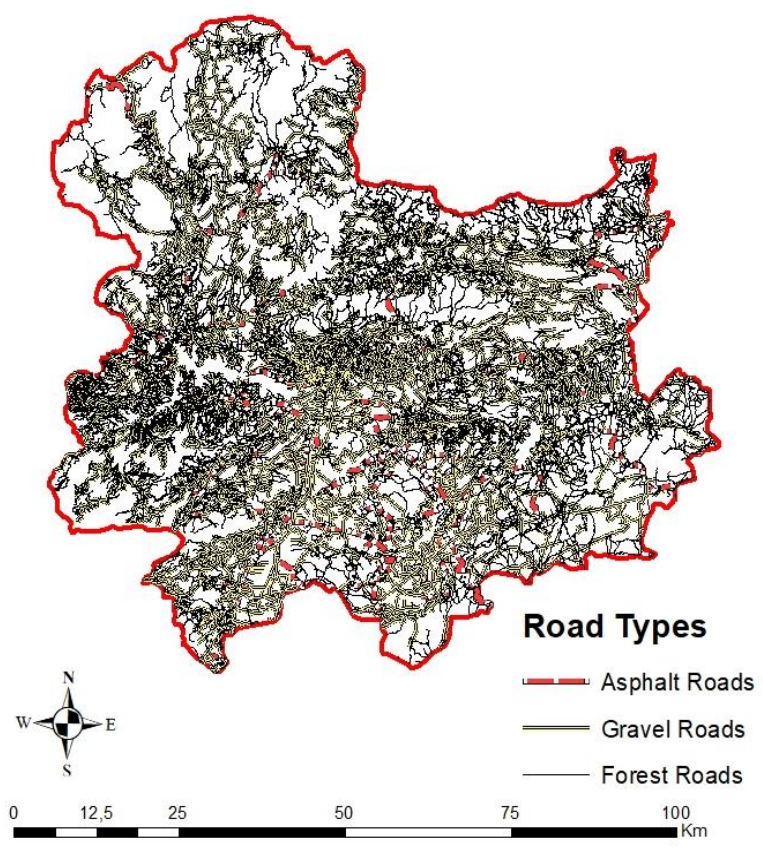

Figure 2. Road network map

The results indicated that the number of land use types in the study area was eighteen (Figure 3 ). The largest land use class was the high forests $(42.09 \%)$, followed by the agricultural lands (35.19\%) (Table 3). The land use types including high forest, coppice forest, forest soil, erosion, nursery, and afforestation areas were reclassified as forest lands. After running reclassification, the total forest area was about $60.17 \%$ of the study area. 
Table 2. Road network statistics within the study area

\begin{tabular}{lccccc}
\hline Road & Number of & Road Lengths & \multicolumn{3}{c}{ Road Status $(\mathrm{km})$} \\
\cline { 4 - 6 } Type & Road Sections & $(\mathrm{km})$ & Good & Average & Poor \\
\hline Asphalt & 2862.0 & 1044.9 & 1044.9 & - & - \\
Gravel & 17507.0 & 6464.2 & 4121.3 & 1190.9 & 1152.0 \\
Forest Road & 13526.0 & 7987.4 & 4532.3 & 3320.1 & 135.0 \\
\hline Total & 33895.0 & 15496.5 & 9698.5 & 4511.0 & 1287.0 \\
\hline
\end{tabular}

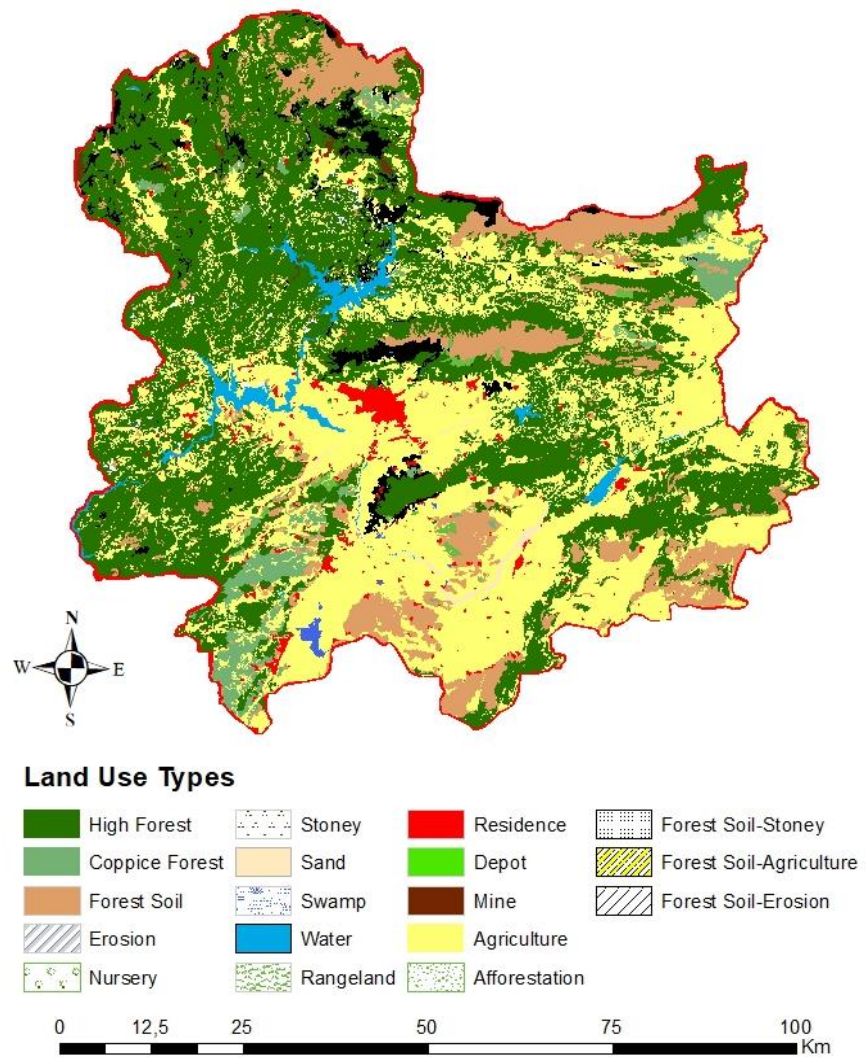

Figure 3. Land use type map

Table 3. Areal distribution of land use types

\begin{tabular}{lc}
\hline Land Use Types & Area (\%) \\
\hline High Forest & 42.09 \\
Agriculture & 35.19 \\
Forest Soil & 11.52 \\
Coppice Forest & 3.04 \\
Residence & 1.89 \\
Forest Soil-Stoney & 1.88 \\
Water & 1.73 \\
Forest Soil-Erosion & 0.99 \\
Sand & 0.48 \\
Afforestation & 0.35 \\
Stoney & 0.35 \\
Swamp & 0.18 \\
Forest Soil-Agriculture & 0.17 \\
Erosion & 0.13 \\
Rangeland & 0.01 \\
Depot & 0.003 \\
Nursery & 0.002 \\
Mine & 0.001 \\
\hline
\end{tabular}

\subsection{Network Analysis}

The areas that can be reached by the firefighting teams within a critical response time were determine by using New Service Area method. Because the study area consisted of the areas sensitive to the forest fires at the first degree, the buffer areas reached through the road network within 20 minutes were investigated. Firstly, accessible forest areas by the firefighting team were determined by considering the existing road network, and then the possible increase in the accessible forest areas was investigated for the forest roads with improved standards in the second scenario.

The results indicated that about $21 \%$ of the total study area could be reached by the firefighting team within the critical response time in the first scenario, while accessible areas increased up to $44 \%$ in the second scenario (Figure 4). It was found that the firefighting teams can reach about $17 \%$ of the forest areas in 20 minutes, considering the existing road network. On the other hand, about $36 \%$ of the forest areas could be reached by firefighting teams considering the forest roads with improved standards (Figure 5). 
In a study conducted by Podolskaia et al. (2019), the transport network model was used to estimate traveling time and distance to a forest fire. A map of the ground fire protection zone was produced to evaluate the ground transport accessibility for three time periods (one, two and three hours). It was found that the forest fires are mostly located within the zones of one- and two-hour's availability. In a similar study conducted by Podolskaia et al. (2020), road data sources were evaluated for the regional forest fire management and it was suggested that the road datasets should be maintained and updated correctly. The results also indicated that within the accessible areas in critical response time, total forest roads subject to improvements were $3627.30 \mathrm{~km}$ in the study area (Figure 6). The added accessible forests in critical response time can be taken into account to estimate potential economic outcomes of improving road standards. The economic value of the accessible forests could be potentially saved from the forest fires by improving road standards can be estimated considering wood-based forest products. In this process, the costs of improving road standards should also be computed based on the cost of road improvement and their technical maintenance costs. Even though improving road standards might result in some additional costs at the road construction stage, maintenance and repair costs may considerably decrease in the long term (Akay et al., 2021).

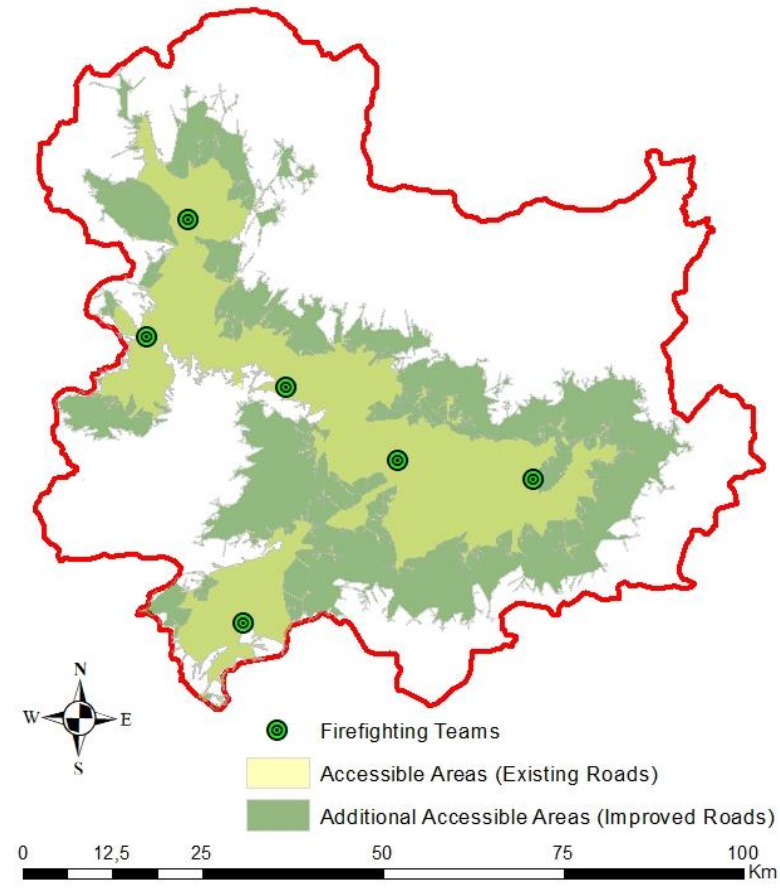

Figure 4. Accessible areas in two scenarios

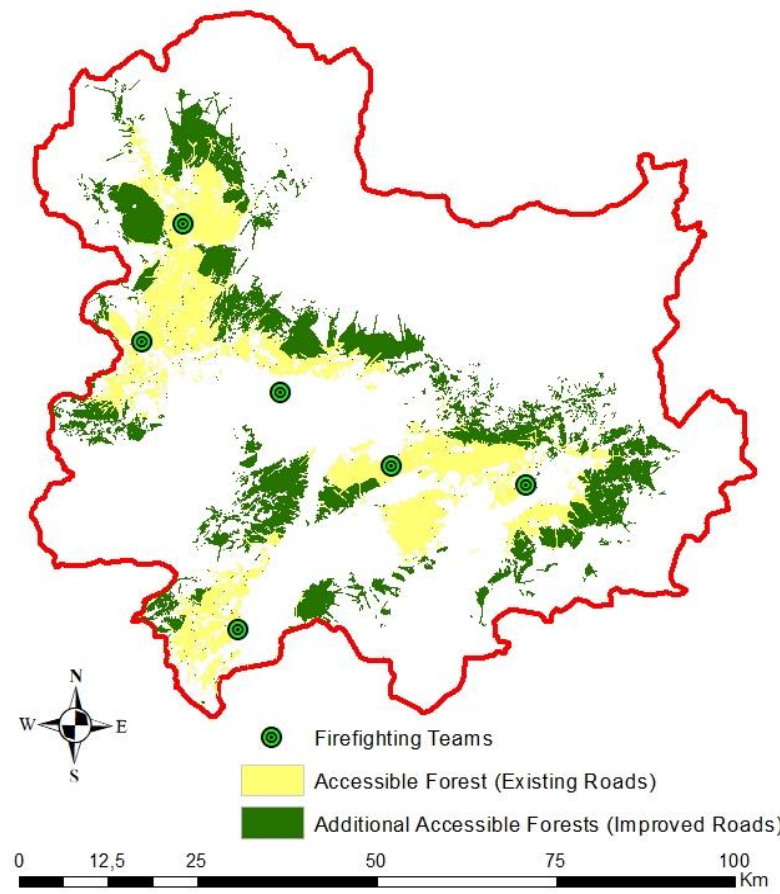

Figure 5. Accessible forest areas in two scenarios 


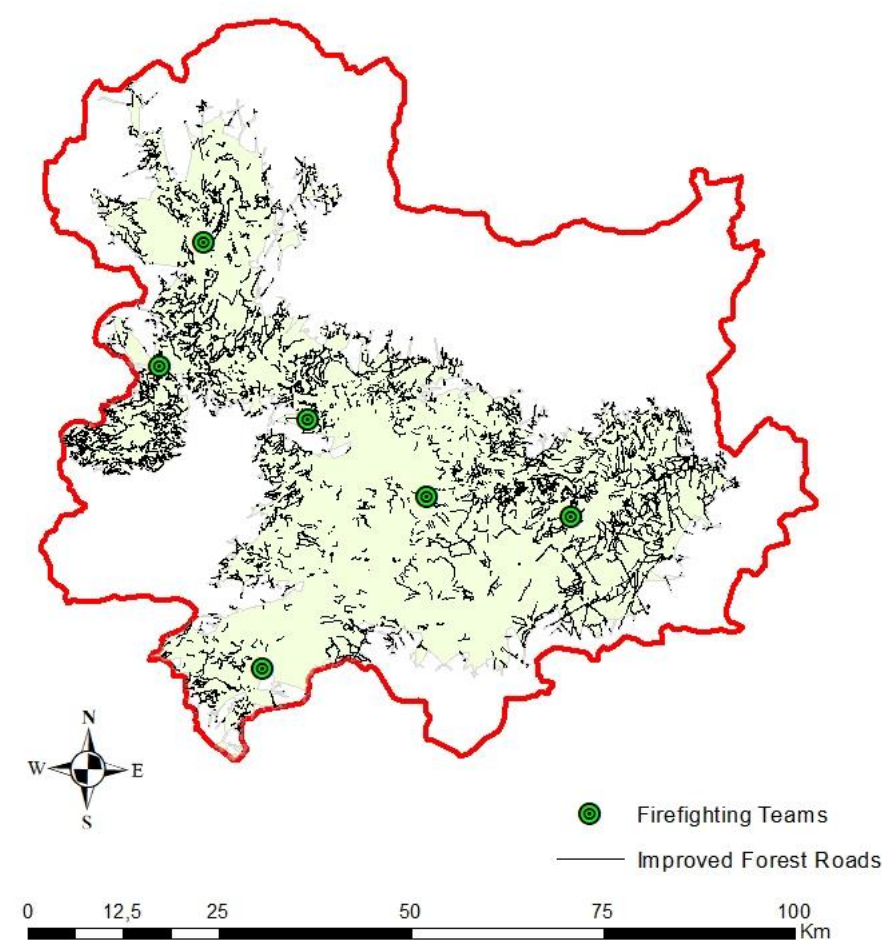

Figure 6 . Forest roads need to be improved in the study area

\section{Conclusions}

Wildfires are inevitable events that seriously damage forests, negatively affect the sustainability of forest resources, and result in biological and ecological impacts on forest ecosystems. In order to minimize the biological and ecological impacts of forest fires on forest ecosystems, the important for firefighting team must reach fire scene as quickly as possible through on-ground transportation. Optimizing the locations of the firefighting team, building new roads, and increasing the design speed on current roads could increase firefighting response capabilities. In this study, GIS techniques were used to assist the forest fire managers to conduct effective firefighting activities by utilizing forest roads with improved standards.

The results of sample application conducted in Kahramanmaras FED indicated that accessible forest areas by the ground-based firefighting teams in the case improved forest roads were more than two times of the accessible forest areas when considering existing road standards. Thus, increasing the design speed on current roads would minimize the arrival time of firefighting teams to the fire and increase the accessible forest areas in critical response time. It would also increase the capabilities of firefighting teams. In future studies, the economic outcomes of improving road standards should be estimated by computing the costs of improving road standards and the economic value of the forests that are potentially saved from the forest fires after improving road standards. Besides, the effects of optimizing the locations of the firefighting teams and constructing new roads on the arrival time of the firefighting teams to fire scenes should be evaluated especially in the firesensitive forest areas.
Ethics Committee Approval: N/A.

Peer-review: Externally peer-reviewed.

Author Contributions: Concept: E.A.E., E.S.P. and Z.U.; Design: E.A.E.; Supervision: E.S.P. and Z.U.; Resources: E.A.E., E.S.P. and Z.U.; Data Collection: E.A.E.; Analysis: E.A.E.; Literature Search: E.A.E. and E.S.P.; Writing Manuscript: E.A.E., E.S.P. and Z.U.; Critical Review: E.S.P. and Z.U.

Conflict of Interest: The authors have no conflicts of interest to declare.

Financial Disclosure: The authors declared that this study has received no financial support

Cite this paper as: Akay, A.E., Podolskaia, E.S., Uçar, Z., 2021. Effects of Improving Forest Road Standards on Shortening the Arrival Time of Ground-based Firefighting Teams Accessing to the Forest Fires European Journal of Forest Engineering, 7(1):32-38.

\section{References}

Akay, A.E., Wing, G.M., Sivrikaya, F., Sakar, D. 2012. A GIS-based decision support system for determining the shortest and safest route to forest fires: a case study in Mediterranean Region of Turkey. Environmental Monitoring and Assessment, 184(3): 1391-1407.

Akay, A. E., Karaş, I. R., Kahraman, I. 2018. Determining the locations of potential firefighting teams by using GIS techniques. The International Archives of the Photogrammetry, Remote Sensing 
and Spatial Information Sciences, XLII-4/W9, International Conference on Geomatics and Geospatial Technology, Kuala Lumpur, Malaysia, 3 5 September 2018.

Akay, A.E., Serin, H., Sessions, J., Bilici, E., Pak, M. 2021. Evaluating the Effects of Improving Forest Road Standards on Economic Value of Forest Products. Croatian Journal of Forest Engineering. 42(2): 245-258.

Bilici, E. 2009. A Study on the Integration of Firebreaks and Fireline with Forest Roads Networks and It's Planning and Construction (A Case Study of Gallipoly National Park) Istanbul University. Faculty of Forestry Journal Series: A, 59(2): 86-102.

Burgan, R.E., Klaver, R.W., Klaver, J.M. 1998. Fuel Models and Fire Potential From Satellite and Surface Observations. International Journal of Wildland Fire 8(3): 159-170.

GDF, 2008. Fire Action Plan. General Directorate of Forestry. Kahramanmaras Forest Regional Directorate, Kahramanmaras. 106 p.

GDF, 2012. Strategic Plan (2013-2017), General Directorate of Forestry, Strategy Development Department, Ankara, 98 p.

Gendreau, M., Laporte, G., Semet, F. 2001. A dynamic model and parallel tabu search heuristic for real-time ambulance relocation. Parallel Computing, 27: 16411653.

Ghiani, G., Guerriero, F., Laporte, G., Musmanno, R. (2003). Real-time vehicle routing: Solution concepts, algorithms and parallel computing strategies. Eur $J$ Oper Res, 151: 1-11.

Ichoua, S., Gendreau, M., Potvin, J.Y. 2000. Diversion issues in real-time vehicle dispatching. Transportation Science, 34: 426-435.

Karabulut M., Karakoç A., Gürbüz M., Kızılelma Y. 2013. Determination of Forest Fire Risk Areas Using Geographical Information Systems in Başkonuş Mountain (Kahramanmaraș). The Journal of International Social Research, 6(24): 171-179.

Keenan, P. 2008. Modelling vehicle routing in GIS. Operational Research, 8(3): 201-218.
Keramitsoglou, I., Kiranoudis, C.T., Sarimveis, H., Sifakis, N. (2004). A multidisciplinary decision support system for forest fire crisis management. Environmental Management, 33(2): 212-225.

Kucuk, O., Unal, S. 2005. Determination of Fire Sensitivity Degree: A Case Study in Tasköprü State Forest Enterprise. Kafkas University Faculty of Forestry Journal, 6(1-2):28-34.

Manussaridis, Z., Mamaloukas, Ch., Spartalis, S. 2007. A VRS Dimension Framework for Effective DSS Design, Applied Mathematical Sciences, 1(42): 20792090.

Podolskaia, E.S., Kovganko, K.K., Ershov, D.V., Shulyak, P.P., and Suchkov, A.I. 2019. Using of transport network model to estimate travelling time and distance for ground access a forest fire. Forest Science Issues, 2(1): 1-24.

Podolskaia E., Ershov D., Kovganko K. 2020. Comparison of data sources on transport infrastructure for the regional forest fire management, Managing forests in the 21st century, Conference at the Potsdam Institute for Climate Impact Research (Potsdam 2020), $59 \mathrm{p}$

Şakar, D. 2010. Determining the Optimum Route Providing the Fastest Transportation to the Fire Areas by Using GIS Based Decision Support System. MSc Thesis. KSU, Faculty of Forestry, Kahramanmaras. Turkey. $81 \mathrm{p}$

Sampson, R.N., Atkinson, R.D., Lewis, J.W. 2000. Mapping Wildfire Hazards and Risks, Food Product Press, 10 Alice Street, Binghamton, NY 13904-1580 USA, 343p.

TIBD, 2010. Traffic Inspection Branch Directorate, İstanbul.

http://trfdenetleme.iem.gov.tr/asiri hiz.aspx $\quad$ Last visit: 15/05/2021.

Zhan, F.B. 1997. Three fastest shortest path algorithms on real road networks: Data structures and procedures. Journal of Geographic Information and Decision Analysis, 1: 70-82. 